\title{
The Model of Service Quality and Visitor Loyalty of Politeknik Negeri Bali’s Library
}

\author{
$1^{\text {st }} \mathrm{Ni}$ Wayan Dewinta Ayuni \\ Department of Accounting \\ Politeknik Negeri Bali \\ Badung. Indonesia \\ dewintaayuni@gmail.com
}

\author{
$2^{\text {nd }}$ Wayan Hesadijaya Utthavi \\ Department of Accounting \\ Politeknik Negeri Bali \\ Badung. Indonesia
}

\begin{abstract}
Libraries as information and science centers for universities must have good service quality. Good service quality will make library visitors feel satisfied. Visitor satisfaction can be reflected in visitor loyalty to the library. Politeknik Negeri Bali (PNB) as one of the universities in Indonesia currently has one library room located on the 2nd floor of the PNB Central Building. Based on the data. the average number of PNB's library visitors in the year 2017 is only $15 \%$ of the total civitas. This number shows that PNB's library has not been optimally utilized and the low rate of visitor loyalty. The purpose of this research is to model the service quality and visitor loyalty of PNB's library. The analysis used is structural equation modeling using five service quality dimensions namely tangible. reliability. responsiveness. assurance. and empathy. The results of the analysis show that the variable of tangible. reliability. and responsiveness have a significant effect on visitor loyalty of PNB's libary.
\end{abstract}

Keywords - library service, visitor loyalty, politeknik negeri bali, structural equation model.

\section{INTRODUCTION}

University as educational program needs facilities to run its task. One of the main facility in university is a library. Libraries are considered as treasures of knowledge and also known as storehouse of knowledge. It consists of reading material like books. journals. films. images. manuscripts. And audio visual materials [1]. Among other facilities provided in university, library plays an important role in catering to their customer's academic needs [2].

Library as the heart of universities must have a good service. The collection assessment was the primary focus of traditional library service quality research. However, for the last ten years, academic library service providers have progressively documented the implications of evaluating their library services. [2].

According to [3], only the customers can judge the quality of services and all other judgments are fundamentally unrelated. The library quality service were developed and applied by them to become Libqual (Library Quality Model). The quality service were divided into Tangible or physichal evidence like collection. facilities in library. and anything that can be seen; Reliability of the ability of the librarians; (3)
Responsiveness of the librarians; Assurance or the sense of safety of visitors to be in the library; and Emphaty of the librarians.

A good service can satisfy the library visitors and bad service can make the visitors feel dissapointed. A satisfied visitor can increase the happiness and raises the visitor loyalty [4]. Studies from [5] and [6] also found that the sense of happiness consumers experience toward a brand has a positive influence on the perceived service quality commitment level and brand loyalty.

According to [7] loyalty is a customer's intention to repurchase a product or service from the same brand or service provider. In other words customer's loyalty can be interpreted as the higher value provided by the specify brand or service provider compared to others [8]. Thus customer's loyalty is considered as a key success factor for a seller or brand over a time [9] [10]. Loyalty can be measured by psychological component and behavioral component where psychological component depends on customer's feeling to rely on a person. products or services of an organization [8]. The behavioral component is based on customer's frequency of visiting a certain shop or service [11].

Politeknik Negeri Bali (PNB) as one of the universities in Indonesia currently has one library room located on the second floor behind the central building of PNB. PNB's library collection in the form of audio visual (CD), books, handouts, research reports, street vendors reports, final assignments, reference books, journals and magazines, tabloids, and newspapers. Based on the data, the average number of PNB's library visitors in 2017 is 770 people each month. The number of visitors is only $15 \%$ of the total PNB civitas. This shows that the PNB's library has not been optimally used and the low rate of library visitor loyalty. Therefore, this study aims to model and determine the relationship of the quality of PNB's library services with visitor loyalty.

\section{RESEARCH METHOD}

This research takes place in Politeknik Negeri Bali (PNB) Library Badung Regency Bali Province Indonesia. The data used in this research is primary data collected by using questionnaire. The population of this research is the visitors of 
PNB's Library and the number of sample used is 100 visitor. The samples taken by using accidental sampling technique which is the visitors who were in the PNB's library when the sample was collected. There are five dimensionals of library service that were used in this research. namely Tangible (T). Reliability (R), Responsiveness (Rp), Assurance (A), and Emphaty (E). These five dimensional of library service are suspected in affecting the loyalty of PNB's library visitors. These variables are also classified as latent variable. The idea of latent variables goes from the assumption that the observed phenomena is affected by unobservable/unmeasureable causes directly [12]. The latent variable can not be measured directly but it is measured by some indicators variables or can be called as manifest variable. The variabels and their indicators that were used in this research is shown in Table 1.

TABLE I. VARIABLES AND INDICATORS DEFINITION

\begin{tabular}{|c|c|c|c|}
\hline Code & Indicator & Code & Indicator \\
\hline $\mathrm{T} 1$ & Cleanliness & Rp1 & $\begin{array}{l}\text { Punctuality in } \\
\text { responding a complaint }\end{array}$ \\
\hline $\mathrm{T} 2$ & Design and Layout & Rp2 & $\begin{array}{l}\text { Perceptive in responding } \\
\text { a complaint }\end{array}$ \\
\hline $\mathrm{T} 3$ & Facilities & Rp3 & $\begin{array}{l}\text { Complaint service is } \\
\text { given according to the } \\
\text { rules }\end{array}$ \\
\hline $\mathrm{T} 4$ & Update Collection & A1 & Safety in Library Room \\
\hline T5 & $\begin{array}{l}\text { Good Condition of } \\
\text { Collection }\end{array}$ & A2 & Safety in Locker \\
\hline T6 & Neatness & A3 & $\begin{array}{l}\text { Ease of Finding } \\
\text { References }\end{array}$ \\
\hline $\mathrm{T} 7$ & Air Circulation & A4 & $\begin{array}{l}\text { The number of } \\
\text { Librarians }\end{array}$ \\
\hline $\mathrm{T} 8$ & Quantity of Collection & A5 & $\begin{array}{l}\text { Librarians have a good } \\
\text { Knowledge }\end{array}$ \\
\hline T9 & Neat Librarians & E1 & Librarians Hospitality \\
\hline $\mathrm{R} 1$ & $\begin{array}{l}\text { Ease of } \\
\text { Administration }\end{array}$ & E2 & Librarians Concern \\
\hline $\mathrm{R} 2$ & $\begin{array}{l}\text { Ease of Lending } \\
\text { Procedure }\end{array}$ & E3 & $\begin{array}{l}\text { Librarians Good } \\
\text { Respons }\end{array}$ \\
\hline $\mathrm{R} 3$ & $\begin{array}{l}\text { Ease of Lending and } \\
\text { Returning Transaction }\end{array}$ & $\mathrm{E} 4$ & $\begin{array}{l}\text { Good Communication of } \\
\text { Librarians }\end{array}$ \\
\hline $\mathrm{R} 4$ & Information Clarity & $\mathrm{L} 1$ & Frequency of Visit \\
\hline \multirow[t]{2}{*}{$\mathrm{R} 5$} & Clarity of Order & $\mathrm{L} 2$ & Repeat Visit \\
\hline & & L3 & Recomendation to Other \\
\hline
\end{tabular}

The method that is used in this research is structural equation model (SEM). SEM is a very general statistical modeling technique. which is widely used in the behavioral sciences. SEM has its root in path analysis which was invented by [13]. It can be viewed as a combination of factor analysis and regression or path analysis. According to this fact. generally SEM is begun by making a path diagram thet represents the relationship between variables in the model [14]. A path diagram consists of boxes and circles. which are connected by arrows. Observed variables (or measured) are represented by a rectangle or square box and latent (or unmeasured) variables are represented by circle or ellipse. Single headed arrows or paths are used to define causal relationship in the model. with the variable at the tail of the arrow causing the variable at the point. Double headed arrows indicate covariances or correlation without causal interpretation. The software used in this research is SmartPLS 3.0 and the analysis steps are (1) Model Conceptualization; (2) Determining Algorithm analysis method. This research use path or structural weighting method; (3) Determining resampling method. which is bootstrapping method; (4) Draw the path diagram; and (5) Model Evaluation using the criteria of loading factor. Average Variance Extracted (AVE), Cronbach's Alpha, Composite Reliability, and T-statistics.

\section{RESULTS AND DISCUSSION}

A. Questionnaire testing

\begin{tabular}{|c|c|c|c|c|c|}
\hline \multicolumn{2}{|c|}{ TABLE II. } & \multicolumn{4}{|c|}{ VALIDITY AND RELIABILITY OF QUESTIONAIRE } \\
\hline Dimensi & Item & $\mathbf{r}$-value & validity & $\begin{array}{c}\text { Cronbach's } \\
\text { Alpha }\end{array}$ & Reliability \\
\hline \multirow{9}{*}{ Tangible } & 1 & 0.590 & Valid & \multirow{9}{*}{0.873} & \multirow{9}{*}{ Reliable } \\
\hline & 2 & 0.474 & Valid & & \\
\hline & 3 & 0.503 & Valid & & \\
\hline & 4 & 0.735 & Valid & & \\
\hline & 5 & 0.597 & Valid & & \\
\hline & 6 & 0.629 & Valid & & \\
\hline & 7 & 0.642 & Valid & & \\
\hline & 8 & 0.729 & Valid & & \\
\hline & 9 & 0.607 & Valid & & \\
\hline \multirow{5}{*}{ Reliability } & 10 & 0.485 & Valid & \multirow{5}{*}{0.874} & \multirow{5}{*}{ Reliable } \\
\hline & 11 & 0.788 & Valid & & \\
\hline & 12 & 0.866 & Valid & & \\
\hline & 13 & 0.776 & Valid & & \\
\hline & 14 & 0.630 & Valid & & \\
\hline \multirow{3}{*}{$\begin{array}{l}\text { Responsive } \\
\text { ness }\end{array}$} & 15 & 0.853 & Valid & \multirow{3}{*}{0.902} & \multirow{3}{*}{ Reliable } \\
\hline & 16 & 0.769 & Valid & & \\
\hline & 17 & 0.826 & Valid & & \\
\hline \multirow{5}{*}{ Assurrance } & 18 & 0.744 & Valid & \multirow{5}{*}{0.764} & \multirow{5}{*}{ Reliable } \\
\hline & 19 & 0.602 & Valid & & \\
\hline & 20 & 0.366 & Valid & & \\
\hline & 21 & 0.551 & Valid & & \\
\hline & 22 & 0.538 & Valid & & \\
\hline \multirow{4}{*}{ Emphaty } & 23 & 0.642 & Valid & \multirow{4}{*}{0.831} & \multirow{4}{*}{ Reliable } \\
\hline & 24 & 0.687 & Valid & & \\
\hline & 25 & 0.651 & Valid & & \\
\hline & 26 & 0.738 & Valid & & \\
\hline \multirow{3}{*}{ Loyalty } & 27 & 0.677 & Valid & \multirow{3}{*}{0.801} & \multirow{3}{*}{ Reliable } \\
\hline & 28 & 0.611 & Valid & & \\
\hline & 29 & 0.733 & Valid & & \\
\hline
\end{tabular}


To begin the analysis, the questionnaire used in this research was tested by using validity and reliability test. The result are shown in the Table 1 . Table 1 shows that all of the item in the questioner have correlation value (r-value) more than r-table (for alpha 0.05 r-table is 0.361 ), so all of the item are stated as valid. While all of the construct have Cronbach's Alpha value greater than 0.6 and stated as reliable. Thus. the questionaire are decent to be used in this research.

\section{B. The Structural Equation Model}

The structural model are shown in the Figure 1. All of the quality service dimensions (tangible, reliability, responsiveness, assurance, and emphaty) and loyalty variable are laten variable with reflectif indicators. Those quality service dimensions are suspected to affect the visitor loyalty of PNB's Library.

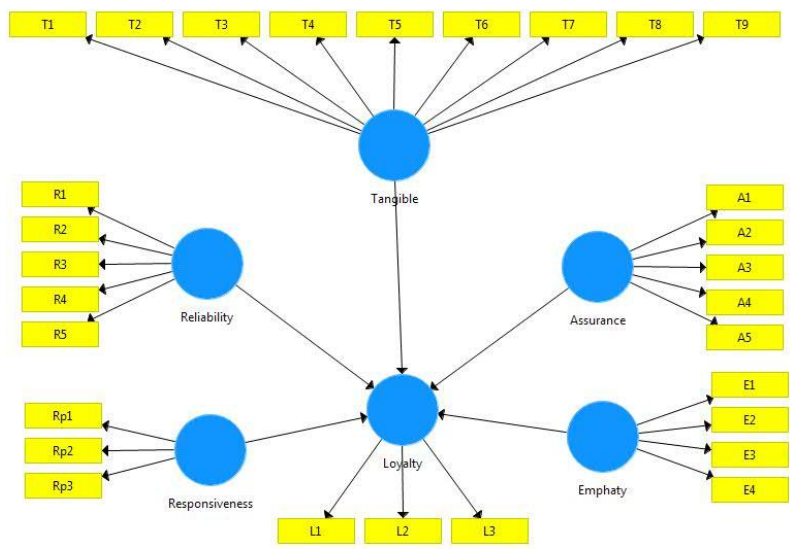

Fig. 1. The Structural Model

\section{Model Evalaluation}

There are some quality criteria in evaluating the measurement model in SEM, which are loading factor for each indicator should be greater than 0.6; Average Variance Extracted (AVE) should be greater than 0.5; Cronbach's Alpha and Composite Reliability of each construct/ variable should be greater than 0.6 [15], [16], [17], [18]. Table III shows the loading factor of each indicator. The result shows that all of the indicators have loading factor greater than 0.6.

The value of AVE. Cronbach's Alpha. and Composite Reliability of each construct or variable are shown in Table IV. Table IV shows that each variable has AVE higher than 0.5, Cronbach's Alpha is higher than 0.6, and Composite Reliability is higher than 0.6. Thus, the model already fit the quality criteria.
TABLE III. LOADING FACTOR OF EACH INDICATOR

\begin{tabular}{|c|c|c|c|c|}
\hline Indicator & LF & & Indicator & LF \\
\hline T1 & 0.744 & & Rp1 & 0.866 \\
\hline T2 & 0.687 & & Rp2 & 0.862 \\
\hline T3 & 0.695 & & Rp3 & 0.873 \\
\hline T4 & 0.674 & & A1 & 0.873 \\
\hline T5 & 0.737 & & A2 & 0.736 \\
\hline T6 & 0.671 & & A3 & 0.655 \\
\hline T7 & 0.668 & & A4 & 0.761 \\
\hline T8 & 0.631 & & A5 & 0.822 \\
\hline T9 & 0.608 & & E1 & 0.876 \\
\hline R1 & 0.751 & & E2 & 0.894 \\
\hline R2 & 0.818 & & E3 & 0.870 \\
\hline R3 & 0.832 & & E4 & 0.854 \\
\hline R4 & 0.627 & & L1 & 0.671 \\
\hline R5 & 0.743 & & L2 & 0.695 \\
\hline & & & L3 & 0.839 \\
\hline
\end{tabular}

TABLE IV. AVE. CRONBACH'S ALPHA. AND COMPOSITE RELIABILITY

\begin{tabular}{|l|c|c|c|}
\multicolumn{1}{|c|}{ TABLE IV. } & AVE. CRONBACH'S ALPHA. AND COMPOSITE RELIABILITY \\
\hline Tangible & AVE & Cronbach's Alpha & Comp Reliabiity \\
\hline Reliabiity & 0.564 & 0.857 & 0.886 \\
\hline Responsive & 0.752 & 0.812 & 0.870 \\
\hline Assurance & 0.597 & 0.837 & 0.901 \\
\hline Emphaty & 0.763 & 0.829 & 0.880 \\
\hline Loyalty & 0.520 & 0.897 & 0.928 \\
\hline
\end{tabular}

The structural model in SEM is evaluated by the value of $\mathrm{R}$ square and $\mathrm{f}$ square. The value of $\mathrm{R}$ square as 0.75 . 0.50 . and 0.25 is concluded as strong. moderate. and weak model; while the value of $\mathrm{f}$ square as 0.02 . 0.15. and 0.35 is concluded that the latent variable has a low. moderate. and high effect on structural level [16]. The result of the structural model evaluation is as shown in table $\mathrm{V}$.

TABLE V. R-SQUARE AND F-SQUARE OF THE MODEL

\begin{tabular}{|l|l|l|}
\hline \multicolumn{1}{|c|}{ Criteria } & Value & classification \\
\hline R square & 0.837 & strong model \\
\hline F square & & high effect \\
\hline Tangible & 0.425 & moderate effect \\
\hline Reliabiity & 0.155 & high effect \\
\hline Responsive & 0.745 & low effect \\
\hline Assurance & 0.000 & low effect \\
\hline Emphaty & 0.030 & \\
\hline
\end{tabular}


The results show that R-square of the model is 0.837 or $83.7 \%$ which is classified as strong model. It means the variance of variable loyalty is explained $83.7 \%$ by the variabel of service quality. The F-square of variable Tangible and Responsiveness are 0.425 and 0.745 which are classified as high effect to loyalty variable. While variable Reliability has a moderate effect on loyalty with the value of F-square as 0.155 . Low effect is given by the variable Assurance and Emphaty.

The significant of each eksogen variable is tested using tstatistic, where if T-value is greater than T-table or the p-value is lower than alpha, the conclusion is the exogen variable has a significant effect to endogen variable. The Figure 2 and Table VI shows the result of $t$-statistic testing.

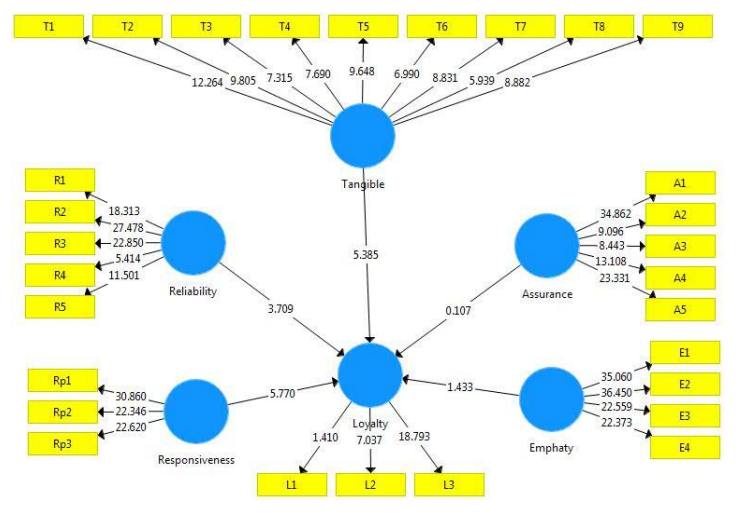

Fig. 2. T-statistics of Model

TABLE VI. T-STAISTICT TSING OF SignificANCY VARIabLE

\begin{tabular}{|l|c|c|c|c|c|}
\hline \multicolumn{1}{|c|}{ Eksogen } & $\begin{array}{c}\text { sample } \\
\text { mean }\end{array}$ & $\begin{array}{c}\text { std } \\
\mathbf{d e v}\end{array}$ & $\begin{array}{c}\mathbf{t} \\
\text { statistic }\end{array}$ & $\begin{array}{c}\mathbf{p} \\
\text { value }\end{array}$ & Conclussion \\
\hline Tangible & 0.425 & 0.076 & 5.531 & 0.000 & Sign \\
\hline Reliabiity & 0.197 & 0.054 & 3.768 & 0.000 & Sign \\
\hline Responsive & 0.542 & 0.097 & 5.611 & 0.000 & Sign \\
\hline Assurance & -0.008 & 0.087 & 0.112 & 0.911 & Not Sign \\
\hline Emphaty & -0.115 & 0.073 & 1.489 & 0.137 & Not Sign \\
\hline
\end{tabular}

The results show that tangible, reliability, and responsiveness has t-statistic as 5.531, 3.768, and 5.611 which are greater than t-table 1.96, and the p-value as 0.000 is lower than alpha 0.05 . It can be concluded that the variable of Tangible, Reliability, and Responsiveness have a significant effect to Visitor Loyalty in PNB's Library. While the variable of Assurance and Emphaty do not have a significant effect to Visitor Loyalty in PNB's Library.

\section{CONCLUSIONS}

According to the analysis that have been done, conclusion obtained that there are three variables in library quality service dimension that affect the visitor loyalty in Politeknik Negeri Bali's Library, namely Tangible, Reliability, and
Responsiveness. While the other variable, assurance and emphaty have no significant affect in visitor loyalty.

There are some suggestions to the Librarians and the leaders of Politeknik Negeri Bali to improve the loyalty of PNB library visitors, which are as following:

1. Make sure to take care of the tangible or physical things like the library facilities, cleanliness of the room, design and layout, the collection must be updated, in good condition and also neat, the air circulation facilities like air conditioner (AC) must be in a good condition, and the librarians also should be in a neat appearance.

2. The library shoud have a clear administrations procedure and process

3. The librarians should increase the good response in taking care of visitor's complaint.

\section{ACKNOWLEDGMENT}

Gratitude and acknowledgement are expressed to Research Centre and Community Service Politeknik Negeri Bali for funding this research. Gratitude also goes to the researcher team who support this research. Without their support, this research would not have been possible. The researcher also wants to gratefully thank to the leaders (Director and Vice Directors) of Politeknik Negeri Bali, librarians, and the visitors of Politeknik Negeri Bali's Library who made this research possible.

\section{REFERENCES}

[1] Patil and Pradhan, "Library promotion practices and marketing of Library services: A role of Library professionals," Procedia - Social and Behavioral Sciences, vol. 133, pp. 249-254, 2014.

[2] J. Mallya and V. Patwardhan, "Hospitality Students' Perception of College Library Service Quality: Importance Performance Analysis," Journal of Library \& Information Technology, Vol. 38, No. 2, March 2018, pp. 125-131, 2018.

[3] V.A. Zeithaml, A. Parasuraman and L.L. Berry, Delivering quality service : Balancing customer perceptions and expectations, Free Press, 1990.

[4] H. Woo and H.J. Ahn, "Big Five Personality and Different Meanings of Happiness of Consumers," Economics and Sociology, Vol. 8, No 3, pp. 145-154, 2015.

[5] C. K. Hsee, Y. Yang, N. Li, and L. Shen, "Wealth, warmth, and wellbeing: Whether happiness is relative or absolute depends on whether it is about money, acquisition, or consumption," Journal of Marketing Research, 46(3), pp. 396-409, 2009.

[6] K. Hellen and M. Saaksjarvi, "Happiness as a predictor of service quality and commitment for utilitarian and hedonic services," Psychology \& Marketing, vol 28, pp. 934- 957, 2011.

[7] D. Sirdeshmukh, J. Singh, and B. Sabol, "Consumer trust, value, and loyalty in relational exchanges," Journal of marketing, vol 66, pp. 15-37, 2002.

[8] Hallowell, "The relationships of customer satisfaction, customer loyalty, and profitability: An empirical study," International journal of service industry management, vol 7, pp. 27-42, 1996.

[9] C. Flavian, M. Guinalíu, and R. Gurrea, "The role played by perceived usability, satisfaction and consumer trust on website loyalty," Information and Management, vol. 43, pp. 1-14, 2006

[10] B. Keating, R. Rugimbana, and A. Quazi, "Differentiating between service quality and relationship quality in cyberspace," Managing Service Quality: An International Journal, vol. 13(3), pp. 217-232, 2003. 
[11] R. Thakur, "Understanding Customer Engagement and Loyalty: A Case of Mobile Devices for Shopping," Journal of Retailing and Consumer Services, vol. 32, pp.151-163, 2016

[12] K.A. Bollen, "Latent Variables in Psychology and the Social Sciences," Annual Review of Psychology, vol. 53, pp. 605-34, 2002.

[13] S. Wright, "Correlation and Causation," Journal of Agricultural Research, vol. 20, pp. 557-585, 1921.

[14] J.J. Hox and T.M. Bechger, "An Introduction to Structural Equation Modeling," Family Science Review, vol. 11, pp.354-73, 1998.

[15] W.W. Chin, The partial least squares approach for structural equation modelling, Modern methods for bussiness research, London: Lawrence earlbaum associates. 1998, pp. 295-236.
[16] W.W. Chin, How to write up and report PLS analysis. Handbook of partial least squares: concepts, methods, and application in marketing and related fields, Berlin: Springer, 2010, pp. 655-690.

[17] J.F. Hair, C.M. Ringle, and M. Sarsted, "PLS-SEM: Indeed a silver bullet," Journal of marketing theory and practice, vol. 19, no. 2, pp. 139150, 2011.

[18] J.F. Hair, M. Sarsted, C.M. Ringle, and J.A. Mena, "An assessment of the use of partial least square structural equation modelling in marketing research," Journal of the academy of marketing science, vol. 40, no. 1 , pp. 414-433, 2012. 